Hum. Hered. 1985;35:I-VI

\title{
Contents, Vol. 35, 1985
}

Managing Editor

L. Beckman, Umeå

Honorary Editor

M. Hauge, Odense

Editorial Board

A.C. Allison, Harrow

A.G. Beam, New York, N.Y.

K. Berg, Oslo

J.A. Book, Uppsala

L.L. Cavalli-Sforza, Stanford,

A. de la Chapelle, Helsinki

TJ. David, Manchester

F.C. Fraser, Montreal

J.A. Fraser Roberts, London

N. Freire-Maia, Curitiba

J. Frézal, Paris

R. Grubb, Lund

K. Henningsen, København

H. Lehmann, Cambridge

J. Lindsten, Stockholm

Margareta Mikkelsen, København

J. Mohr, København

Calif. A.E. Mourant, London

J.V. Neel, Ann Arbor, Mich. U. Pettersson, Uppsala Marianne Rasmuson, Umeå S. Refsum,

Oslo L.D. Sanghvi, Bombay M. Siniscalco, Napoli F. Vogel, Heidelberg M. Whittaker, Exeter

Contents Vol. 35,1985

No. 1 Original Paper

Uncertainty in Identification of Blood Group A Subtypes by Agglutination Test

Yoshida, A.; Dave, V.; Prchal, J 1

Study of Human Red Cell NADH Diaphorase (Diai) in the Italian Population

Beretta, M.; Santachiara-Benerecetti, A.S 7

Gc Serum Groups in Schizophrenia

Rudduck, C; Franzén, G.; Hansson, A.; Rorsman, B 11

Variant Multiple Endocrine Neoplasia I(MEN IbuПП): Further Studies and Non-Linkage to HLA 
Bear, J.C.; Briones-Urbina, R.; Fahey, J.F.; Farid, N.R

Genetic Heterogeneity of Delta-Aminolevulinate Dehydrase and Phosphoglycolate Phosphatase in North-West Spain

Caeiro, B.; Rey, D 21

Haptoglobin Groups in Dementia of Alzheimer Type and Multi-Infarct Dementia

Fröhlander, N.; Adolfsson, R 25

C6 Polymorphism in Japanese: Typing by Agarose Gel Isoelectric Focusing-Immunofixation Nishimukai, H.; Kitamura, H.; Kishida, T.; Tamaki, Y 30

A Comparative Study of Albumin Variants Found in Brazil

Franco, M.H.L.P.; Salzano, F.M 34

Some Remarks on Linkage with a Quantitative Character

Bener, A 39

Segregation and Linkage Analyses of 72 Leprosy Pedigrees

Haile, R.W.C.; Iselius, L.; Fine, P.E.M.; Morton, N.E 43

Short Communications

Atrichias and Hypotrichoses: A Brief Review with Description of a Recessive Atrichia in two Brothers

Pinheiro, M.; Freire-Maia, N 53

Transferrin Variant D Chi in Tribals in Eastern India

Giri, A.K.; Datta, S.; Talukder, G.; Sharma, A 56

Glutamate Pyruvate Transaminase Null Allele (GPT' $>$ ) in the Navajo

Crist, M.; Heckenlively, J.R.. Field, L.L.; Sparkes, M.C.; Farson, C; Spence, M.A.;

Sparkes, R.S 59

Alpha-1-Antitrypsin: Frequencies of PiM Subtypes and Serum Concentration in the Japanese Population

Ohtani, H.; Saito, M 62

No. 2 Original Paper

Haptoglobin and Transferrin Types in Schizophrenia

Rudduck, C; Franzén, G.; Fröhlander, N.; Lindström, L 65

C3 Variants in Japanese

Nishimukai, H.; Kitamura, H.; Sano, Y.; Tamaki, Y 69

The Use of Incompletely Linked Markers in Genetic Counseling: Accuracy versus Linkage Asmussen, M.A 73

Transferrin C Subtypes and Occupational Photodermatosis of the Face

Beckman, L.; Beckman, G.; Cedergren, B., Göransson, K..; Hallqvist, E.-B.: Sikström, C. 89

Contents

III

Phosphoglucomutase (PGMi) Subtypes in a Finnish Population Determined by Isoelectric

Focusing in Agarose Gel

Lukka, M; Ehnholm, C; Kuusi, T 95

An Extended Survey of the Genetic Polymorphism at the Human Coagulation Factor XIII:

A Subunit Structural Locus

Castle, S.L.; Board, P.G 101

Red Cell Enzyme Types in Rheumatic Diseases

Krylov, M.Y.; Gurbanov, V.P.; Makarov, V.V.; Benevolenskaya, L.I

Short Communications 
No Association between GLO I and Hp in the Austrian Population

Pausch, V.; Weirather, M.; Dub. E.; Göbel, J.; Mayr, W.R 111

Sneezing on Exposure to Bright Light as an Inherited Response

Forrester, J.M 113

Haptoglobin and Transferrin Types in Eti-Turks

Dinçol, G.; Aksoy, M.; Erdem, S.; Dinçol, K. 115

Frequencies of Ceruloplasmin Alleles in a Chinese Population

Mei-lin, Z.; Qi-long, Y.; Lin-fang, W.; Chih-chuan, L 117

Polymorphism of Red Cell Glyoxalase I in Serbia, Yugoslavia

Kalimanovska, V.; Majkic-Singh, N.; Jelic-Ivanovic, Z 120

C3 Polymorphism in Greece

Germenis, A.; Kolitsopoulos, A.; Dimopoulos, A.-M.; Fertakis. A 123

Incidence of C5 Isozyme of Serum Cholinesterase (E; Locus) in Populations of Andhra

Pradesh, South India

Rao, P.R.; Char, K..S.N.; Theophilus, J.; Parasa, L.; Hussain, S 126

No. 3 Original Paper

Multiallelic Restriction Fragment Polymorphisms in Genetic Counseling: Population Genetic

Considerations

Asmussen, M.A.; Clegg, M.T 129

Frequency of Glucose-6-Phosphate Dehydrogenase Deficiency in Sickle-Cell Disease. A

Study in Saudi Arabia

Warsy, A.S 143

A Sero-Biochemical Genetic Study of Jalari and Brahmin Caste Populations of Andhra

Pradesh, India

Naidu, J.M.; Mohrenweiser, H.W.; Nee, J.V 148

A Silent Transferrin Allele in a Finnish Family

Lukka, M.; Ehnholm, C 157

ABO Associations with Blood Pressure, Serum Lipids and Lipoproteins, and Anthropometric Measures

Borecki, LB.; Elston, R.C.; Rosenbaum, PA.; Srinivasan, S.R.; Berenson, G.S 161

Population Genetics of Polymorphisms in Cardiff Newborn. Relationship between Blood

Group and Allozyme Heterozygosity and Birth Weight

Ward, R.D.; Sarfarazi, M.; Azimi-Garakani, C; Beardmore, J.A 171

PGM1 Null Allele Detected in a Caucasian Mother-Son Pair

Ward, L.J.; Elston, R.C.; Keats, B.J.B.; Graham, J.B178

Familial Resemblance in Maximal Heart Rate, Blood Lactate and Aerobic Power

Lesage, R.; Simoneau, J.-A.; Jobin, J.; Leblanc, J.; Bouchard. C 182

IV Contents

Short Communications

Population and Mother-Child Study of Esterase D in Sweden

Wetterling, G 190

ai-Antitrypsin Types in Schizophrenia

Rudduck, C; Franzén, G.; Lindström, L 193

Noncongenital Dominant Universal Alopecia in a Family

Freire-Maia, D.V.; Ramos, C.C 196

Haptoglobin-ABO Association. Data from Northern Sweden 
Fröhlander, N 198

No. 4 Original Paper

Genetic Relationships between Indians and Their Neighboring Populations

Roychoudhury, A.K.; Nei, M 201

Haptoglobin Groups and Rheumatoid Arthritis

Dahlqvist, S.R.; Fröhlander, N 207

Red Cell NADH Diaphorase Variants in Japanese

Shimizu, K..; Keino, H.; Mizutani, A.; Itoh, T.; Nishigaki, 1

Variability of Selection Opportunities with Changing Socio-Cultural Environments

Rajanikumari, J.; Srikumari, C.R.; Rao, T.V 218

Complement Factor $\mathrm{C} 4$ in Schizophrenia

Rudduck, C; Beckman, L.; Franzén, G.; Jacobsson, L.; Lindström, L 223

Nonorgan-Specific Autoantibodies and Immunoglobulin Allotypes in Relatives of Patients with Monoclonal Gammopathy

Youinou, P.; Fauchier,C; Prou, O.; Rivat-Peran, L.; Jouquan, J.; Moysan, J.F.; Le Menn, G. 227

Segregation Analysis of Ocular Refraction and Myopia

Ashton, G.C 232

Bf and C3 Complement Types in Rheumatoid Arthritis

Dahlqvist, S.R.; Beckman, G.; Beckman, L 240

DR Antigens and Bf Allotypes in North-East England

Papiha, S.S.; Duggan-Keen, M.F.; Rodger, R.S.E 246

A Genetic and Demographic Study of Hemophilia A in Brazil

Alexandre, CO.P.; Roisenberg, 1250

C3 and C6 Complement Types in Schizophrenia

Rudduck, C; Beckman, L.; Franzén, G.; Lindström, L 255

Placental Alkaline Phosphatase Polymorphism in Northern Greece

Kouvatsi, A.; Triantaphyllidis, CD 259

Short Communications

Association between C3 Complement Types and Bronchial Asthma

Srivastava, N.; Gupta, S.P.; Srivastava, L.M 263

A Possible Clinical Implication of Homozygous Inversions of 9qh Regions with Cornelia de Lange Syndrome (CLS)

Babu, K.A.; Verma, R.S.; Rodriguez, J.; Rosenfeld, W.; Jhaveri, R.C 265

Association between C3 Complement Types and Indian Childhood Cirrhosis

Srivastava, N.; Srivastava, L.M 268

Letter to the Editor

Statistical Testing in Dermatoglyphic Studies

Lendrem, D 271

Contents

$\mathrm{V}$

No. 5 Original Paper

Elcctrophoretic Subtyping of Phosphoglucomutase Locus 1 (PGM,) Polymorphism in the

Czechoslovakian Populations

Ranzani, G.N.; Brdicka, R.; Antonini, G.; Pardini, R.; Santachiara-Benerecetti, A.S. . 273

Transferrin C Subtypes and Rheumatoid Arthritis

Rantapää Dahlqvist, S.; Beckman, L 279 
Some Red Cell Antigens in the Hausa Population of Northern Nigeria Kulkarni, A.G.; Ibazebo, R.O.; Dunn, D.T.; Fleming, A.F 283

Genetic Linkage Analysis of the Carpal Tunnel Syndrome

Sparkes, R.S.; Spence, M.A.; Gottlieb, N.L.; Gray, R.G.; Crist, M.; Sparkes, M.C.; Marazita, M 288

A Two-Step Test for Heterogeneity of Fst Values at Different Loci

Barbujani, G 292

Automating Data Manipulation for Genetic Analysis Using a Data Base Management System

Farrer, L.A.; Haines, J.L.; Yount, E.A 296

Serum Protein Polymorphisms in Patients with Primary Sjögren's Syndrome

Mitchell, R.J.; Fabb, S.A.; Whittingham, S 302

HLA Antigens and Other Genetic Markers in the Mapuche Indians of Argentina

Haas, E.J.C.; Salzano, F.M.; Araujo, H.A.; Grossman, F.; Barbetti, A.; Weimer, T.A.;

Franco, M.H.L.P.; Verruno, L.; Nasif, O.; Morales, V.H.; Arienti, R 306

Within- and Between-Zygosty Variance in Oral Traits among LIS and Punjabi Twins

Corruccini, R.S.; Sharma, K 314

Comparison of Two Preliminary Methods of Quantitative Linkage Analysis

Kammerer, CM.; MacCluer, J.W 319

Glutathione Reductase Deficiency in Association with Sickle Cell and Thalassaemia Genes

in Saudi Populations

El-Hazmi, M.A.F.; Warsy, A.S 326

Human Chromosomal Heteromorphisms in Delhi Newborns. II. Analysis of C-Band Size

Heteromorphisms in Chromosomes 1,9 and 16

Potluri, V.R.; Singh, I.P.; Bhasin, M.K 333

Short Communications

AK and ADA Polymorphisms in South Sardinia

Floris, R.; Mameli, G.E.; Porcella, P.; Vona, G

Distribution of Transferrin C Subtypes Among the Bedouin and Non-Bedouin Populations

of Jordan

Saha, N 341

Gene Frequencies of Plasminogen in Switzerland

Dimo-Simonin, N.; Brandt-Casadevall, C; Gujer, H.-R

Placental-Soluble Aconitase Polymorphism in Japanese

Oya, M.; Shibata, R.; Kido, A.; Komatsu, N 346

No. 6 Original Paper

Human Placental Glucose Dehydrogenase: IEF Polymorphism in Two Italian Populations

and Enzyme Activity in the Six Common Phenotypes

Scacchi, R.; Corbo, R.M.; Calzolari, E.; Laconi, G.; Palmarino, R.; Lucarelli, P 349

The Rh Phenotype r'r' in Polynesians

Lyne, C.J.; Clark, P.L.; Lyne, M.A.; Woodfield, D.G 